\title{
Phemphigoid gestationis
}

\author{
Vera Furtado Veiga, Fernanda Santos, Andreia Antunes, Isabel Duarte
}

Department of Gynecology/ Obstetrics, Centro Hospitalar de Leiria, Leiria, Portugal

\section{Correspondence to}

Dr Vera Furtado Veiga, veralfveiga@gmail.com

Accepted 25 May 2018

\section{DESCRIPTION}

A 32-year-old nulliparous woman presented at 33 weeks' gestation with intense pruritus initiated 1 month earlier. She was under treatment for scabies, with no improvement. She was healthy and her pregnancy had had no intercurrences so far. During the physical examination at the emergency room, extensive erythematous plaques with vesicles and bullae could be seen on her abdomen, trunk, neck and all four extremeties (figures 1 and 2).

Due to the severity of her symptoms, she was admitted to the obstetrics ward in order to undergo intravenous (prednisone $20 \mathrm{mg}$ id) and topical corticotherapy, as well as an oral antihistamine (hydroxyzine $25 \mathrm{mg}$ id). The full blood count and biochemical work-up revealed mild anaemia with no changes in liver function markers, through which intrahepatic cholestasis of pregnancy was excluded as a diagnosis.

A dermatology consult was requested, in which context a biopsy was performed. The histology report was inconclusive in differentiating between phemphigoid gestationis and polymorphic eruption of pregnancy; because of this, an ELISA test was done, which was positive for BP180 antibodies ( $>200 \mathrm{UA} / \mathrm{mL}$, reference value $<20 \mathrm{UA} / \mathrm{mL}$ ) and direct immunofluorescence confirming the diagnosis of phemphigoid gestationis.

The patient was discharged 1 week later under oral therapy including, once again, a corticosteroid and an antihistamine. At 38 weeks, she delivered a male newborn of $2980 \mathrm{~g}$ with no skin lesions. On her third day post partum, however, she had a new flare-up, having to undergo 3 months of therapy with subcutaneous goserelin. In the 4 years since, she has not showed any signs of recurrence.

Phemphigoid gestationis is a rare $(1: 5000)$ autoimmune dermatosis of pregnancy, although it can persist through puerperium, as was the case with this patient, and/or be exarcebated with menses and oral contraceptive intake. ${ }^{1}$ The

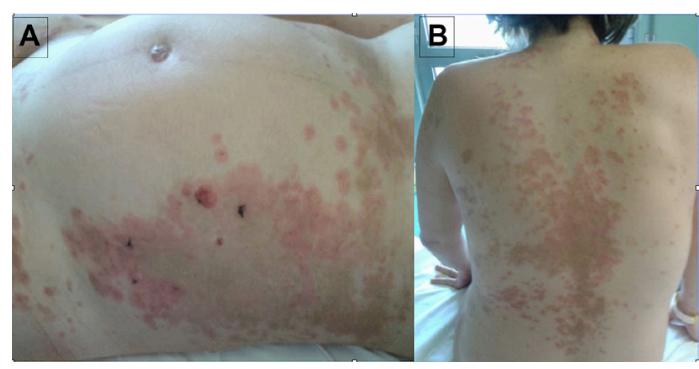

Figure 1 Macroscopic skin lesions of 33-week pregnant woman: initially, lesions are like erythematous papules or targetoid lesions ( $\mathrm{A}$, abdomen; $\mathrm{B}$, back).

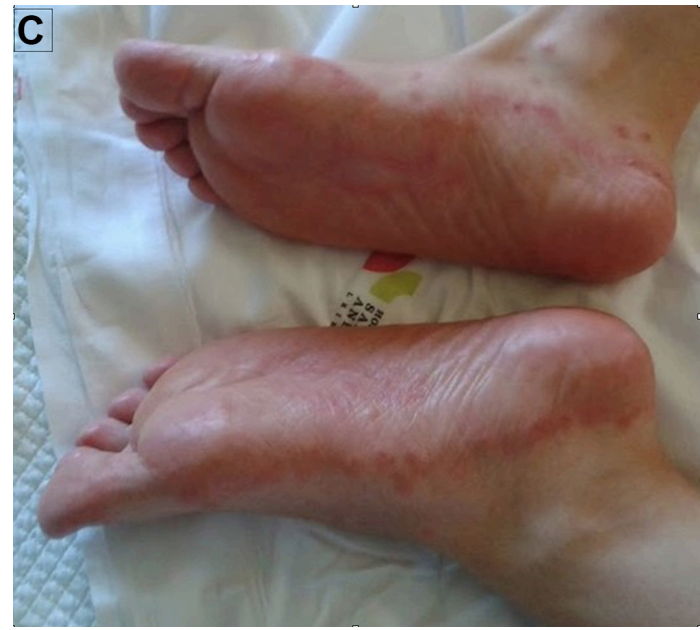

Figure 2 Macroscopic skin lesions of 33-week pregnant woman: over time, small vesicles or bullae appear on normal skin or on top of urticarial plaques ( $C$, feet).

blisters may appear on both the mother and the newborn (10\% of all cases), but here only the mother was affected.

Pruritus is the main complaint in phemphigoid gestationis. $^{2}$ One of its most important differential diagnoses is polymorphic urticarial papules and plaques of pregnancy: in the present case, both histology and direct immunofluorescence were needed to confirm the suspicion. Corticosteroids are the first-line systemic therapy for the disease.

\section{Learning points}

- This pregnancy-related blistering dermatosis is associated with poorer obstetric outcomes, like fetal growth restriction and prematurity.

- Immunofluorescence plays an essential role in diagnosis, showing linear deposits of complement component C3 along the basement membrane.

- Women should be informed of the disease's risk of recurrence in subsequent pregnancies, which is $5 \%-8 \%$.

Acknowledgements This paper was presented as Poster Presentation on March 2014 at a scientific reunion of Portuguese Society of Obstetrics and Fetal-Maternal Medicine.

Contributors VFV and FS were responsible for the study concept and design, revision of the literature and drafting of the manuscript. AA and ID contributed to study supervision and critical revision of the manuscript.

Funding The authors have not declared a specific grant for this research from any funding agency in the public, commercial or not-for-profit sectors.

Competing interests None declared. 


\section{Images in...}

\section{Patient consent Obtained.}

Provenance and peer review Not commissioned; externally peer reviewed.

(C) BMJ Publishing Group Ltd (unless otherwise stated in the text of the article) 2018. All rights reserved. No commercial use is permitted unless otherwise expressly granted.

\section{REFERENCES}

1 Huilaja L, Mäkikallio K, Tasanen K, et al. Gestational pemphigoid. Orphanet J Rare Dis 2014;9:136.

2 Campbell SM, Balazs K, Conroy M, et al. Pemphigoid gestationis: a case report and review of the literature. Cutis 2011;88:21-6.

Copyright 2018 BMJ Publishing Group. All rights reserved. For permission to reuse any of this content visit

http://group.bmj.com/group/rights-licensing/permissions.

BMJ Case Report Fellows may re-use this article for personal use and teaching without any further permission.

Become a Fellow of BMJ Case Reports today and you can:

- Submit as many cases as you like

- Enjoy fast sympathetic peer review and rapid publication of accepted articles

- Access all the published articles

Re-use any of the published material for personal use and teaching without further permission

For information on Institutional Fellowships contact consortiasales@bmjgroup.com

Visit casereports.bmj.com for more articles like this and to become a Fellow 